\title{
Transport of Carbonate Ions by Novel Cellulose Fiber Supported Solid Membrane
}

\author{
A. G. Gaikwad * \\ CE\&PD Division, National Chemical Laboratory, Pune 411008, India
}

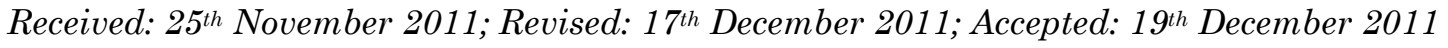

\begin{abstract}
Transport of carbonate ions was explored through fiber supported solid membrane. A novel fiber supported solid membrane was prepared by chemical modification of cellulose fiber with citric acid, 2'2-bipyridine and magnesium carbonate. The factors affecting the permeability of carbonate ions such as immobilization of citric acid-magnesium metal ion -2'2-bipyridine complex ( 0 to $2.5 \mathrm{mmol} / \mathrm{g}$ range) over cellulose fiber, carbonate ion concentration in source phase and $\mathrm{NaOH}$ concentration in receiving phase were investigated. Kinetic of carbonate, sulfate, and nitrate ions was investigated through fiber supported solid membrane. Transport of carbonate ions with/without bubbling of $\mathrm{CO}_{2}(0$ to $10 \mathrm{ml} / \mathrm{min})$ in source phase was explored from source to receiving phase. The novel idea is to explore the adsorptive transport of $\mathrm{CO}_{2}$ from source to receiving phase through cellulose fiber containing magnesium metal ion organic framework. Copyright (C) 2012 BCREC UNDIP. All rights reserved.
\end{abstract}

Keywords: Polymer membrane; carbonate ion; citric acid; metal ion; 2 2'-bipyridine

How to Cite: A.G. Gaikwad. (2012). Transport of Carbonate Ions by Novel Cellulose Fiber Supported Solid Membrane. Bulletin of Chemical Reaction Engineering \& Catalysis, 7 (1): 49- 57

Permalink: http://ejournal.undip.ac.id/index.php/bcrec/article/view/1225

\section{Introduction}

Porous metal-organic frameworks (MOFs) functional materials have great potentials in various applications [1-2]. The equilibration and transport properties are important of different gases mixtures in a bio-metal organic framework (bio-MOF). Metal organic framework materials are useful for storing and separation of gases [3-4]. Metal organic framework (MOF-74) of cobalt, magnesium, nickel, and zinc metal centers had been tested for the removal of ammonia, cyanogen chloride, and sulfur dioxide from air under humid conditions [5-6]. Supported amine or ionic liquids materials and metal-organic framework materials

* Corresponding Author

E-mail: ag.gaikwad@ncl.res.in (A. G. Gaikwad) were highlighted for $\mathrm{CO}_{2}$ capture [7-8]. Metalorganic framework compounds after chemically modifications were used to capture gases. Incorporated metal organic framework in fibers by covalent bonding and then using the chemistry of the fiber surface were used to capture gases. A metal-organic framework (MOF) having ability of hydrogen-bonding donor and acceptor were proved to be effective for selective sorption [9-12]. Anion separations were carried out with metal-organic frameworks (MOFs) [13-14]. Chemically modified cellulose fibers were used for the separation and pre-concentration of metal ions [15-16]. Generally, metal organic framework (MOF) was used for the 
sequestration or storing and transportation of chemical species. In plants, the metal organic framework is used to transport and convert the chemical species by using capillary action mechanism. Thus, metal organic framework (MOF) chemically fixed (attached) on polymeric materials could be used to transport and chemically convert the chemical species. In this paper, the explored idea is adsorptive transport of $\mathrm{CO}_{2}$ through cellulose fiber supported solid magnesium metal ion organic framework membrane. However, there are some reports on the chemically conversion of chemical species through metal organic framework [17-18]. The synthesis of metal organic framework and also the designs of the systems are the important aspects to explore.

B- diketones of magnesium form 1:1 complexes with bidentate ligands such as 2 2'-bipyridine, ethylene glycol and 1, 10 phenanthroline. Tris(bipyridine)ruthenium(II) dichloride, $\left[\mathrm{Ru}(\text { bipy })_{3}\right] \mathrm{Cl}_{2}$ hexahydrate, red crystalline salt with distinctive optical properties, was explored in point of view all of the properties of interest of the cation $\left[\mathrm{Ru}(\mathrm{bipy})_{3}\right]^{2+}$. The chlorides of these complexes can be replaced with other anions. Photoredox catalysis $\left[\mathrm{Ru}(\text { bipy) }]_{3}\right]^{2+}$ with visible light had been used as a tool for preparative organic chemistry [19-20]. Bipyridine complexes absorb in the visible region. The electronic transitions were attributed to metal-to-ligand charge transfer. In the tris(bipy) complexes, three bipyridine molecules are coordinated to a metal ion, $\left[\mathrm{M}\left(\text { bipy }_{3}\right]^{\mathrm{n}+}(\mathrm{M}=\mathrm{Cr}, \mathrm{Fe}, \mathrm{Co}, \mathrm{Ru}, \mathrm{Rh}\right.$ and bipy $=2,2$ '-bipyridine). These complexes have sixcoordinated, octahedral structures. Under strongly reducing conditions, most tris(bipy) complexes can be reduced to neutral derivatives containing bipy- ligands (viz. $\mathrm{M}$ (bipy) ${ }_{3}$ where $\mathrm{M}=$ $\mathrm{Al}, \mathrm{Cr}, \mathrm{Si})$. The related N-heterocyclic ligand phenanthroline does not have the same conformational flexibility and tends to bind metal ions more strongly [21]. The compound, $\left[\mathrm{Mg}\left(\mathrm{C}_{10} \mathrm{H}_{8} \mathrm{~N}_{2}\right)\left(\mathrm{H}_{2} \mathrm{O}\right)_{4}\right]\left(\mathrm{C}_{7} \mathrm{H}_{4} \mathrm{FO}_{2}\right)_{2}$, consists of a bivalent $\left[\mathrm{Mg}\left(\mathrm{C}_{10} \mathrm{H}_{8} \mathrm{~N}_{2}\right)\left(\mathrm{H}_{2} \mathrm{O}\right)_{4}\right]_{2+}$ cation and two 4fluorbenzoate anions. In the complex cation, the $\mathrm{Mg}(\mathrm{II})$ atom is coordinated by two $\mathrm{N}$ atoms from a 2,2'-bipyridine ligand and four water $\mathrm{O}$ atoms in a distorted $\mathrm{MgN}_{2} \mathrm{O}_{4}$ octa-hedral geometry [22-23]. The formation constants for the complexes of $\mathrm{Mg}^{2+}, \mathrm{Ca}^{2+}, \mathrm{Sr}^{2+}$ and $\mathrm{Ba}^{2+}$ with 2,2'-bipyridyl and 1,10-phenanthroline had been determined from $\mathrm{pH}$ measurements in aqueous solution, at 10, 25 and 40 degrees and various ionic strengths in the range $0.05-0.95 \mathrm{M}$ [24]. The complexes $\mathrm{Cp}_{2} \mathrm{ML}_{2}$, with $\mathrm{M}=\mathrm{Ti}, \mathrm{Zr}$ and $\mathrm{H}_{\mathrm{f}}$, and $\mathrm{L}_{2}=$ bipyridyl, biquinoline and 4,4'-dimethyl-2,2'-bipyridyl, were prepared in excellent yields via magnesium reduction of the respective group 4 metallocene dichlorides in THF solution [25]. Since, the metal organic framework has high surface area and porosity, so far, the developed metal organic framework was used to capture and sequester the gases such as hydrogen, $\mathrm{CO}_{2}$, methane, etc. However, here, the idea is to immobilize the metal organic framework on cellulose fiber and its utilization for the transport of chemical species through it especially for transport of carbonate ions. Such studies are lacking.

For the separation and recovery of cation and anions, the different methods such precipitation, gravimetric, ion exchange, solvent extraction, etc. are used. However, these methods have the disadvantages such as phase separation problems, time consuming, loss of costly reagents and solvent, multistep processes, etc. Membrane technique eliminates all such problems occurred during the operations. Supported membrane technique is an on line and continuous process can be carried out several hours. Therefore, fiber supported solid membrane technique is an emerging technique for the separation and recovery of metal ions, cations and also anions.

Porous polymer fibers such as cellulose containing amine groups with porous metal organic framework chemically attached could be used for adsorbing and transporting the acidic gases such as $\mathrm{CO}_{2}, \mathrm{SO}_{2}, \mathrm{NO}_{2}$, etc. Therefore an attempt has been made to attach the 2'2bipyridine through magnesium complex to the cellulose citrate framework. In this work, the kinetic of carbonate ion was explored through fiber supported solid membrane containing cellulose citrate, magnesium ion, and 2'2bipyridine. Adsorptive reactive transport of $\mathrm{CO}_{2}$ was explored by bubbling $\mathrm{CO}_{2}$ in source solution from source to receiving phase through cellulose fiber supported solid magnesium metal ion organic framework membrane. Fiber supported solid membrane technique could be used for the transport or selective removal or recovery or separation of metal ions and also anions from the geological sites such as in mining industries. By keeping these aspects front side, in this paper, the basic studies of kinetic of transport of carbonate ions were explored the cellulose fiber supported solid membrane.

\section{Materials and Methods}

\subsection{Chemicals}

The acid solutions were prepared from 
concentrated acids (MERCK, India Ltd.,) by using distilled and de-ionized water. The pretreated cellulose porous solid fibers were (Aldrich Chemicals) used for their chemical modification. The standard solution for the analysis of carbonate was prepared from the sodium carbonate (MERCK Chemicals). The standardization of carbonate ion was done either by acid-base titration or ion selective electrode depending on the carbonate ion concentrations. Carbonate ions were prepared by bubbling $\mathrm{CO}_{2}$ in aqueous solution and then carbonate ions were standardized by standard methods. Magnesium was determined by EDTA titration, precipitation and flame photometry depending on concentration. Citric acid was estimated by acidbase titration. 1,10 phenanthroline or $2,2^{\prime}$ bipyridine was determined acid-base titration or spectrophotometry depending on concentration. The fiber supported solid membrane cell was used to measure the permeability coefficient (P) (Figure 1). The carbonate ion concentration was determined with respect to time from the source and receiving solutions.

\subsection{Chemically modification of cellulose Fiber}

The porous solid fibers were used with dimensions, the diameter $0.027 \mathrm{~cm}(270 \mu \mathrm{m})$, porosity 30 to $50 \%$ and cross section area $5.73 \mathrm{x}$ $10^{-4} \mathrm{~cm}^{2}$. The cellulose fibers were modified chemically by the scheme.
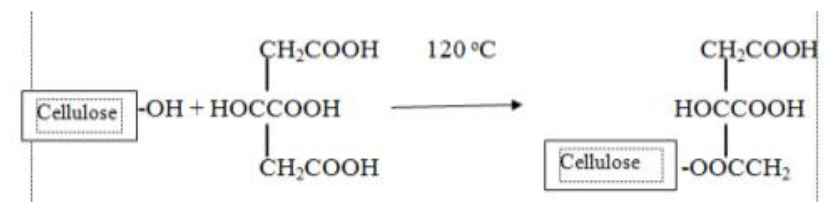

The modified cellulose fiber supported solid membrane was prepared [26-29]. The pre-treated cellulose fibers were treated with $0.5 \mathrm{M}$ citric acid

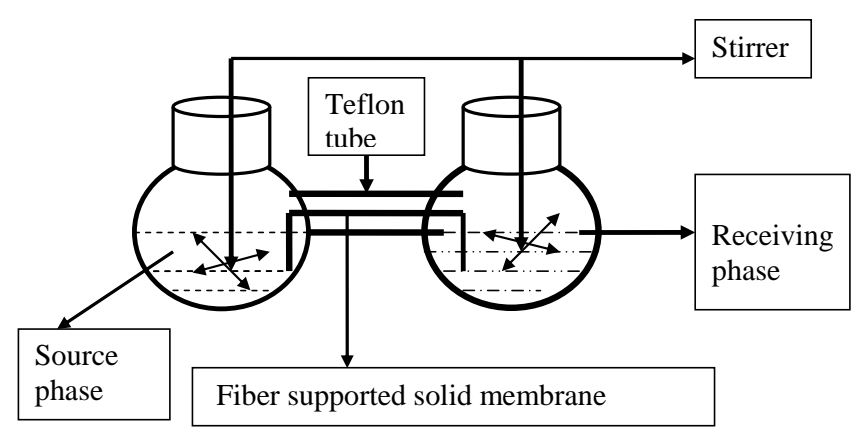

Fig. 1: The schematic presentation of fiber supported solid membrane cell in the ratio of $1: 12$ (cellulose fiber: acid, w/v) under stirring for $30 \mathrm{~min}$, and then keeping in a stainless steel reactor and dried at $50{ }^{\circ} \mathrm{C}$ in a forced air oven for $24 \mathrm{~h}$. The thermo-chemical esterification of citric acid and cellulose fiber was carried out in the oven at $120{ }^{\circ} \mathrm{C}$ for $90 \mathrm{~min}$. The esterified cellulose fibers were washed with distilled water until the filtrate is free from citric acid (Tested as no turbidity with $0.1 \mathrm{M}$ lead (II) nitrate solution). The combined complex of magnesium with esterified cellulose fibers and 2 '2-bipyridine were formed with the treatment of magnesium salt by stirring. The excess magnesium carbonate and 2'2-bipyridine were removed by washing thoroughly with distilled water and then ethanol. The wet modified cellulose fibers were dried at $50{ }^{\circ} \mathrm{C}$ for $24 \mathrm{~h}$, and then preserved in desiccators for further use.

\subsection{Procedure}

In the source phase compartment of the cellulose fiber supported solid membrane cell, a suitable carbonate ion concentration in $15 \mathrm{ml}$ was used. In the receiving phase compartment of cellulose fiber supported solid membrane cell, 15 $\mathrm{ml}$ of aqueous solution containing the appropriate concentration of sodium hydroxide was used. The source and receiving phases were connected by fiber supported solid membrane through a teflon tube. The transport of carbonate ions through cellulose fiber supported solid membrane was studied by varying the experimental parameters such as cellulose fiber membrane length, carbonate ion concentration in the source phase, stirring of bulk phases, $\mathrm{NaOH}$ concentration in receiving phase, etc. The transported carbonate ions per unit membrane length, cross section area and time were estimated. In order to test the adsorptive transport of $\mathrm{CO}_{2}$ through cellulose fiber supported solid membrane, the permeability of carbonate ions were determined with/without bubbling $\mathrm{CO}_{2}$ with a flow rate $0,1,2,4,6,8,10$ $\mathrm{ml} / \mathrm{min}$ in the source phase. The samples of the source and receiving phases were analyzed for carbonate ions with respect to time.

\section{Results and Discussion}

\subsection{Mechanism of transport of carbonate ions}

In the carbonate ion transport mechanism, the transport of carbonate ions from source to receiving through fiber supported solid membrane is illustrated in the Figure 2. There is no continuous flow of mobile phase either from 
source or receiving phase through the fiber supported solid membrane. The capillary action mechanism in the porous fiber helps to maintain the liquid in the fiber during the transport of carbonate ions. However, there is a transport of carbonate ions from the source through the membrane to receiving phase due the driving forces of receiving phase. Moreover, the ion exchange and diffusion of chemical species through the fiber supported solid membrane are the important parameters responsible for the transport of carbonate ions. In the fiber supported solid membrane phase, chemically bonded citric acid, magnesium metal ion and 2'2-bipyridine to cellulose fibers are used as the membrane barriers in between source and receiving phases. The driving forces of alkali concentration in the receiving phase enhance the transport of carbonate ions from source to receiving through membrane phase.

For the calculation of permeability coefficient $(\mathrm{P})$, the rate of change of concentration of carbonate ion (Cs) in the source phase or receiving phase with respect to time $(t)$ through a cross section area (A), volume of source phase (Vs) and fiber supported solid membrane phase length (l) can be given by the Equations (1, 2), where, $\mathrm{k}$ is a rate constant [30].

$-\mathrm{dC}_{\mathrm{s}} / \mathrm{dt}=\mathrm{k} \cdot \mathrm{A} /\left(\mathrm{V}_{\mathrm{s}} \cdot \mathrm{l}\right) \cdot \mathrm{C}_{0^{\mathrm{s}}}$

$\mathrm{d}_{\mathrm{r}} / \mathrm{dt}=\mathrm{k} \cdot \mathrm{A} /\left(\mathrm{V}_{\mathrm{r}} \mathrm{l}\right) \cdot \mathrm{C}_{\mathrm{o}} \mathrm{r}$

After integrating the equation (1) or (2), the permeability coefficient $(\mathrm{P})$ of transport of carbonate ions is given by the equations $(3,4)$.

$\operatorname{Ln}\left(\mathrm{C}_{\mathrm{t}} \mathrm{s} / \mathrm{C}_{0} \mathrm{~s}\right)=-\left(\mathrm{A} / \mathrm{V}_{\mathrm{s}}\right) \cdot(\mathrm{P} / \mathrm{l}) \cdot \mathrm{t}$

$\operatorname{Ln}\left(\mathrm{C}_{t} \mathrm{r} / \mathrm{C}_{0} \mathrm{r}\right)=\left(\mathrm{A} / \mathrm{V}_{\mathrm{r}}\right) \cdot(\mathrm{P} / \mathrm{l}) \cdot \mathrm{t}$

The calculated permeability coefficient $(\mathrm{P})$ is used to interpret the data of transport of carbonate

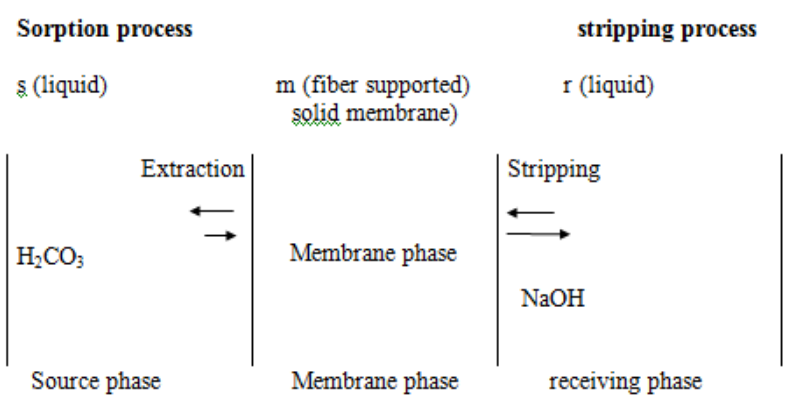

Fig. 2: Illustration of transport of carbonate ions through fiber supported solid membrane ions through porous solid fiber supported solid membrane at different experimental conditions.

\section{Kinetic curves for carbonate ion}

The carbonate ion concentration variation with respect to time was determined in source and receiving phases. In Figure 3, the kinetic curves for carbonate ion concentration in the source and receiving phases are given. The results indicate that the transport of carbonate ions was observed with respect to time.

The reactions occurred in the fiber supported solid membrane system are the anion exchange of carbonate ions from source solution through membrane $(\mathrm{R}-\mathrm{N}$, citric acid through magnesium and 2'2-bipyridine bonded to cellulose) to receiving phase $(\mathrm{NaOH})$ are given by following equations:

$$
\mathrm{HHCO}_{3, \mathrm{~s}}+\mathrm{R}-\mathrm{N}, \mathrm{m} \rightarrow \mathrm{R}-\mathrm{N}-\mathrm{H}-\mathrm{HCO}_{3}, \mathrm{~m} \text { (extraction) }
$$

$$
\begin{aligned}
& \mathrm{R}-\mathrm{N}-\mathrm{H}-\mathrm{HCO}_{3, \mathrm{~m}}+2 \mathrm{NaOH}, \mathrm{r} \rightarrow \mathrm{R}-\mathrm{N}, \mathrm{m}+\mathrm{Na}_{2} \mathrm{CO}_{3, \mathrm{r}}+ \\
& 2 \mathrm{H}_{2} \mathrm{O}, \mathrm{r}
\end{aligned}
$$

\subsection{Determination of permeability coefficient}

The transport of carbonate ions through fiber supported solid membrane from source to receiving solution was explored. To estimate the permeability coefficient $(\mathrm{P})$ of carbonate ions, the carbonate ion concentration in the source and receiving phase with respect to time was determined. From the slope of the plots of log $\left(\mathrm{C}_{t} / \mathrm{C}_{0}\right)$ vs. $\mathrm{t}$, the permeability coefficient $(\mathrm{P})$ was determined by using the values of $\mathrm{A}(5.73 \times 10-4$ $\mathrm{cm}^{2}$, cross section area), V (15 ml, volume) and l (2 $\mathrm{cm}$, length). The plots of $\log \left(\mathrm{C}_{t} / \mathrm{C}_{0}\right)$ with respect to

Table 1: Effect of rpm stirring speed on $\log \mathrm{P}$ values for carbonate ion, carbonate ion $=0.001 \mathrm{M}$ and $\mathrm{NaOH}$ $=0.01 \mathrm{M}$

\begin{tabular}{cc}
\hline $\begin{array}{c}\text { Fiber supported membrane } \\
\text { length, cm }\end{array}$ & $\begin{array}{c}\text { Log } \mathbf{P} \\
\text { Carbonate ion, }\end{array}$ \\
\hline 40 & 1.33 \\
60 & 1.53 \\
80 & 1.74 \\
100 & 1.95 \\
110 & 2.12 \\
120 & 2.19 \\
130 & 2.20 \\
140 & 2.21 \\
\hline
\end{tabular}


time are given in Figure 4.

\subsection{Effect of stirring on permeability coefficient}

In order to achieve the effective transport of carbonate ions from source to receiving phase through membrane phase, the stirring of bulk source and receiving phases are essential to minimize the diffusion layer in between the interfaces of the chemical species in bulk solutions and also in solutions in fibers. Source and receiving bulk phases were stirred in the range from 50 to $140 \mathrm{rpm}$. In Table 1 , the log $\mathrm{P}$ values with respect to stirring (in rpm) of bulk phases are given. The permeability coefficient $\mathrm{P}$ is increased with the increased in rpm until 120 . In the range of rpm 120 to 140 , there is no change in $\log \mathrm{P}$ values. However, further experimental studies were carried out at $125 \mathrm{rpm}$.

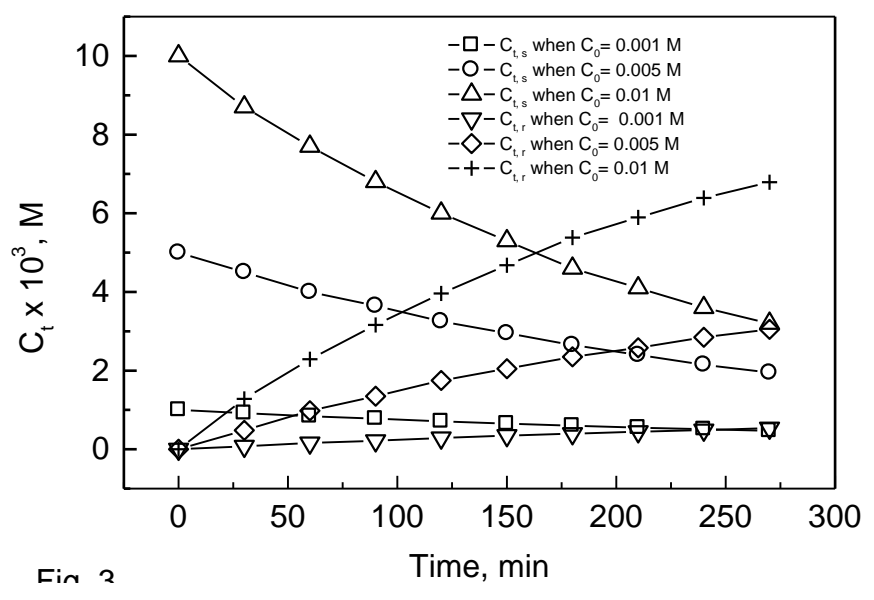

Fig. 3: The concentration of carbonate ions in source and receiving phases versus time

Table 2: Effect of carbonate ion concentration in source solution on $\mathrm{EF}$ values, $\mathrm{NaOH}=0.01 \mathrm{M}$

\begin{tabular}{cc}
\hline $\begin{array}{c}\text { Log } \\
\text { [Carbonate] }\end{array}$ & $\begin{array}{c}\text { EF } \\
\text { Carbonate ion }\end{array}$ \\
\hline-6 & 2.63 \\
-5 & 2.14 \\
-4 & 1.95 \\
-3 & 1.62 \\
-2 & 1.59 \\
\hline
\end{tabular}

\subsection{Effect of fiber membrane length on permeability coefficient}

The travel path of carbonate ions depends on the fiber supported membrane length, cross section area of fiber supported solid membrane, concentration in source and receiving phase, stripping agent in receiving phase. The length of fiber supported solid membrane determines the time required for travelling of chemical species. Therefore, the length of fiber supported solid membrane is an essential parameter to explore. The fiber membrane length is varied in between 1 to $10 \mathrm{~cm}$ (Figure 5). Log $\mathrm{P}$ decreases with increasing in length of fiber supported solid membrane.

\subsection{Effect of $\mathrm{NaOH}$ on permeability coefficient}

Stripping agent $\mathrm{NaOH}$ concentration in receiving phase is an effective parameter to transport the carbonate ions from source solution through membrane to receiving phase. Therefore,

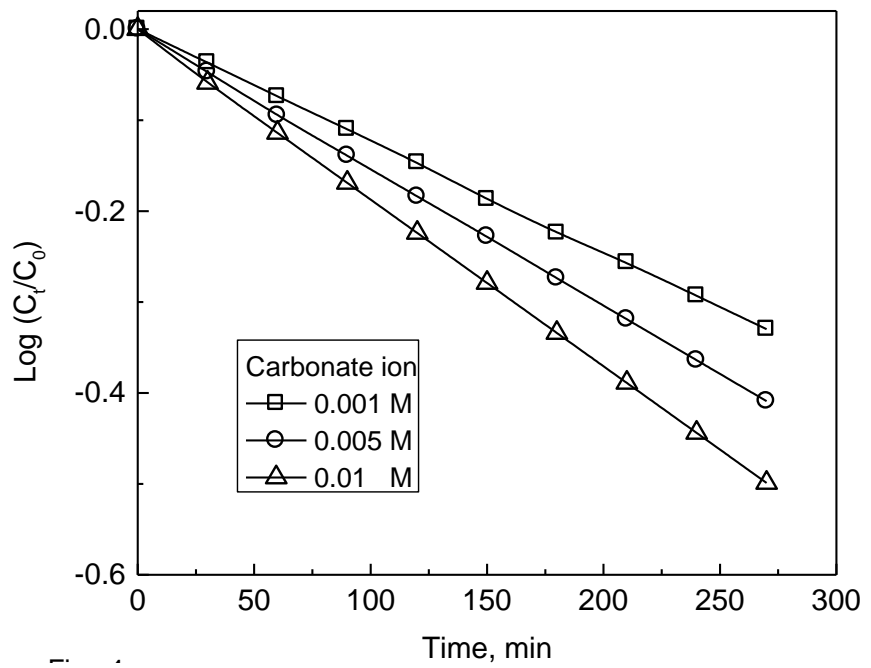

Fig. 4: The plot of $\log \mathrm{C}_{\mathrm{t}} / \mathrm{C}_{0}$ versus time, $\mathrm{NaOH}=$ $0.05 \mathrm{M}$

Table 3: Effect of $\mathrm{CO}_{2}$ flow rate on $\log \mathrm{P}$, carbonate $=0.001$ and $\mathrm{NaOH}=0.05 \mathrm{M}$

\begin{tabular}{cc}
\hline $\mathbf{C O}_{2}, \mathbf{m l} / \mathbf{m i n}$ & $\begin{array}{c}\text { Log } \mathbf{P} \\
\text { Carbonate ion }\end{array}$ \\
\hline 0 & 2.21 \\
1 & 2.31 \\
2 & 2.39 \\
4 & 2.51 \\
6 & 2.63 \\
8 & 2.78 \\
10 & 2.99 \\
\hline
\end{tabular}


Table 4: Effect of citric acid-metal ion- 2'2bipyridine and citric acid-metal ion- 1,10 phenanthroline loading on $\log \mathrm{P}$, carbonate $=0.001$ and $\mathrm{NaOH}=0.05 \mathrm{M}$

\section{Cellulose-citric acid-metal ion- 2'2-bipyridine orCellulose- cit- ric acid-metal ion- 1,10 phe- nanthroline, loading 2.15 $\mathrm{mmol} / \mathrm{g}$}

\begin{tabular}{|c|c|}
\hline $\begin{array}{l}\text { Cellulose-citric acid-iron- } 22 \\
\text { bipyridine }\end{array}$ & 2.31 \\
\hline $\begin{array}{l}\text { Cellulose-citric acid- magnanese - } 2 \\
2 \text { ' bipyridine- }\end{array}$ & 2.13 \\
\hline $\begin{array}{l}\text { Cellulose-citric acid-cobalt- } 22 \\
\text { bipyridine }\end{array}$ & 2.09 \\
\hline $\begin{array}{l}\text { Cellulose-citric acid-copper-2 2' } \\
\text { bipyridine }\end{array}$ & 2.27 \\
\hline $\begin{array}{l}\text { Cellulose-citric acid -zinc- } 22 \\
\text { bipyridine }\end{array}$ & 2.34 \\
\hline $\begin{array}{l}\text { Cellulose-citric acid-ruthenium- } 2 \\
\text { 2' bipyridine }\end{array}$ & 2,39 \\
\hline $\begin{array}{l}\text { Cellulose-citric acid -rhodium -2 2' } \\
\text { bipyridine }\end{array}$ & 2.37 \\
\hline $\begin{array}{l}\text { Cellulose-citric acid -platinum -2 2' } \\
\text { bipyridine }\end{array}$ & 2.38 \\
\hline $\begin{array}{l}\text { Cellulose-citric acid-iron-1,10 phe- } \\
\text { nanthroline }\end{array}$ & 2.18 \\
\hline $\begin{array}{l}\text { Cellulose-citric acid-maganese - } \\
1,10 \text { phenanthroline }\end{array}$ & 2.09 \\
\hline $\begin{array}{l}\text { Cellulose-citric acid-cobalt-1,10 } \\
\text { phenanthroline }\end{array}$ & 2.16 \\
\hline $\begin{array}{l}\text { Cellulose-citric acid -copper- } 1,10 \\
\text { phenanthroline }\end{array}$ & 2.21 \\
\hline $\begin{array}{l}\text { Cellulose-citric acid -zinc-1,10 phe- } \\
\text { nanthroline }\end{array}$ & 2.34 \\
\hline $\begin{array}{l}\text { Cellulose-citric acid-ruthenium- } \\
1,10 \text { phenanthroline }\end{array}$ & 2.37 \\
\hline $\begin{array}{l}\text { Cellulose-citric acid -rhodium- } \\
1,10 \text { phenanthroline }\end{array}$ & 2.38 \\
\hline $\begin{array}{l}\text { Cellulose-citric acid-platinum-1,10 } \\
\text { phenanthroline }\end{array}$ & 2.37 \\
\hline
\end{tabular}

$\mathrm{NaOH}$ concentration in receiving phase was varied from 0.0001 to $0.01 \mathrm{M}$. In Figure 6, log $\mathrm{P}$ against concentration of $\mathrm{NaOH}$ is given. With the increased in $\mathrm{NaOH}$ concentration in receiving phase, the transport of carbonate ions from source phase to receiving phase is increased.

\subsection{Effect of citric acid-Mg-2'2-bipyridine complex on cellulose fiber on permeability coefficient}

Citric acid-Mg-2'2-Bipyridine is a solid

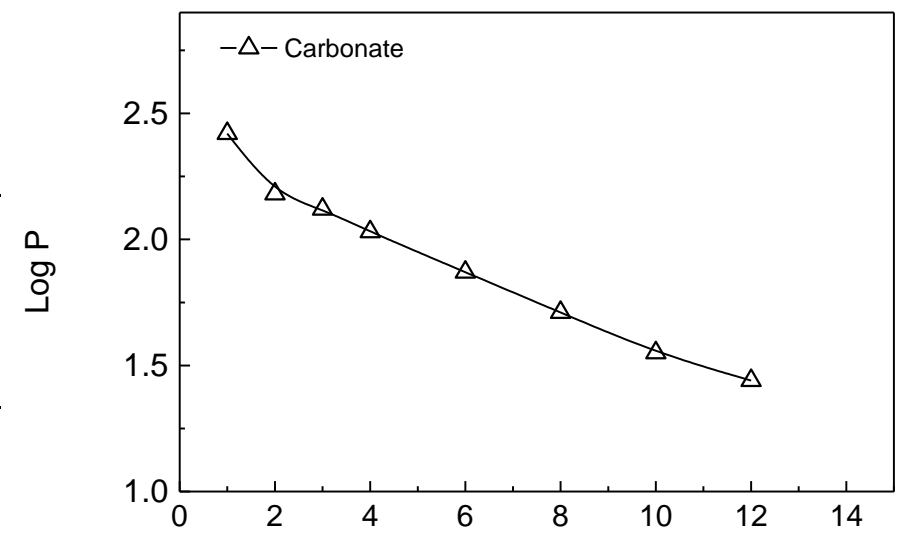

Fig. 5 Length of fiber membrane, $\mathrm{cm}$

Fig. 5: Effect of fiber membrane length on $\log \mathrm{P}$, carbonate $=0.001 \mathrm{M}$ and $\mathrm{NaOH}=0.05 \mathrm{M}$

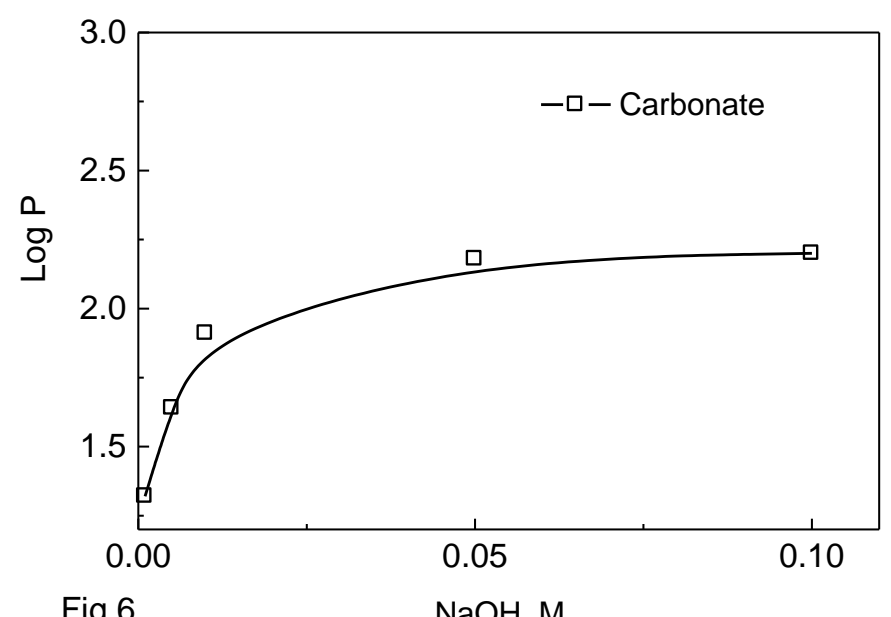

Fig 6

Fig. 6: Effect of $\mathrm{NaOH}$ concentration in receiving phase on $\log \mathrm{P}$

membrane phase on cellulose fiber. Chemically bonded citric acid was varied by means of chemical reaction over cellulose fibers. In Figure 7, transport studies of carbonate ion with variation of loading of citric acid-Mg-2'2-bipyridine over cellulose fibers were shown. The observed results show that $\log \mathrm{P}$ value increases with the increase in loading of citric acid-Mg-2'2-bipyridine over cellulose fibers.

\subsection{Enrichment of carbonate ion}

The enrichment of carbonate ion from dilute solution was carried out with variation of 


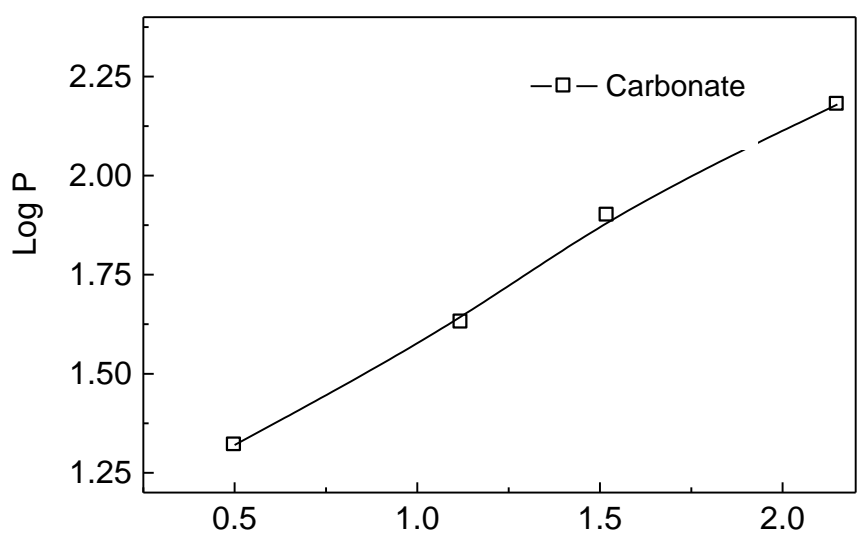

Fig $7 \quad$ Citric acid-Mg- 2 '2-bipyridine, mmol/g

Fig. 7: Effect of loading of citric acid-Mg-2 '2bipyridine on cellulose fiber on $\log \mathrm{P}$, carbonate $=$ $0.001 \mathrm{M}$ and $\mathrm{NaOH}=0.1 \mathrm{M}$

carbonate ion in source solution. In Table 2, the enrichment factor (EF) with respect to carbonate ion concentration in source solution is given. The EF was observed higher when the low concentration of carbonate ion was used in source solution.

\subsection{Permeability coefficient for carbonate, sulfate and nitrate ions}

Permeability coefficient of carbonate, nitrate and sulfate ion was explored through fiber supported solid membrane. In Figure 8, the results of permeability coefficient of carbonate, sulfate and nitrate ions are given. The results show that carbonate ions travel faster than that of sulfate and nitrate ions.

\subsection{Effect of bubbling of $\mathrm{CO}_{2}$ in source phase on permeability coefficient}

In order to test the adsorptive reactive transport of $\mathrm{CO}_{2}$ through fiber supported solid membrane, some experiments were carried out by bubbling $\mathrm{CO}_{2}$ through source solution with different flow rates such as $0,1,2,4,6,8$, and 10 $\mathrm{ml} / \mathrm{min}$. The permeability coefficients of carbonate ions with and without bubbling of $\mathrm{CO}_{2}$ were determined. In Table $3, \log \mathrm{P}$ values were given against the carbonate ion concentration in presence or absence of bubbling $\mathrm{CO}_{2}$ through source phase. The results show that the bubbling of $\mathrm{CO}_{2}$ in source phase increases the $\log \mathrm{P}$ values of carbonate ions. These results indicate that the adsorptive reactive transport of $\mathrm{CO}_{2}$ was observed.

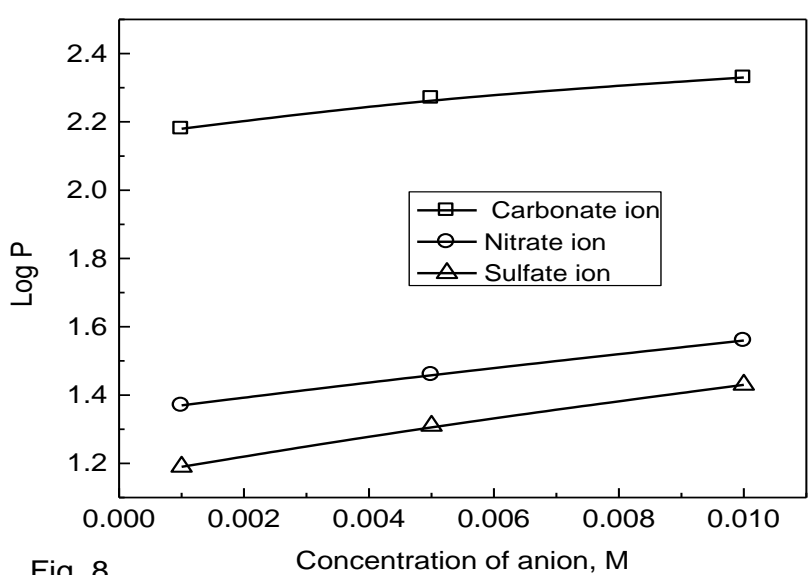

Fig. 8: Log $\mathrm{P}$ values for carbonate, nitrate and sulfate anions, $\mathrm{NaOH}=0.01 \mathrm{M}$

\subsection{Log $P$ values for the different metal - ligand complexes}

Different metal complexes such as 2 ', bipyridine-iron, 2 2' bipyridine-magnanese, 2 2' bipyridine -cobalt, 2 2' bipyridine -copper, 2 2' bipyridine-zinc, 22 ' bipyridine-ruthenium, 22 ' bipyridine-rodium, 22 ' bipyridine-platinum, 1,10 phenanthroline-iron, 1,10 phenanthrolinemaganese, 1,10 phenanthroline-cobalt, 1,10 phenanthroline-copper, 1,10 phenanthroline-zinc, 1,10 phenanthroline-ruthenium, $\quad 1,10$ phenanthroline-rodium and 1,10 phenanthrolineplatinum were attached to the cellulose citrate. The $\log \mathrm{P}$ values of carbonate ion transport were determined (Table 4). The results indicate the cellulose citrate-metal ion-2'2 bipyridine or cellulose citrate-metal ion-1,10 phenanthroline complexes transport the carbonate ion from source through membrane to receiving phase

\section{Conclusion}

Kinetic studies of carbonate ion were done through fiber supported solid membrane. Transport of carbonate ions were studied with variation of different experimental parameters such as fiber supported solid membrane length, stirring of bulk phases, concentrations of carbonate ions in source solution, $\mathrm{NaOH}$ concentration in receiving phase, etc. Kinetic shows that the carbonate ions travel faster than that of sulfate and nitrate ions. The adsorptive reactive transport of $\mathrm{CO}_{2}$ was observed through fiber supported solid membrane. The proposed fiber supported solid membrane technique has advantages over the other techniques such as precipitation, 
gravimetric, solvent extraction, ion exchange, etc. The advantages include the on line process, no loss of solvent or extractant, less time required, no involved multiple step, etc. Fiber supported solid membrane technique could be used for the transport or selective removal or recovery or separation of metal ions and also anions from the geological sites such as in mining industries

\section{Nomenclature}

P Permeability coefficient of carbonate ions

$\mathrm{V} \quad$ Volume in $\mathrm{ml}(\mathrm{mL})$

$1 \quad$ Length of cellulose porous solid fiber, $\mathrm{cm}$

A Cross section area of the cellulose porous solid fibers, $\mathrm{cm}^{2}$

C Concentration, $\mathrm{M}(\mathrm{mol} / \mathrm{l})$

$\mathrm{t}$ Time, min

EF Enrichment factor

\section{Subscripts}

$\mathrm{m}$ membrane phase

s source phase

$\mathrm{r} \quad$ receiving phase

\section{References}

[1] Shengqian, M., 2009. Gas Adsorption Applications of Porous Metal-Organic Frameworks. Pure Applied Chemistry. 81 (12): 2235-2251.

[2] Romain, C.; Catherine, R.; Francis, S.; Patricia, H.; Christian S.; Menaschi, H.; Gérard, F.; JeanMarc, G.; Frédéric, L.; Jong-San. C.; Young-Kyu, H.; Oleg, L.; Stuart, T., and Gustaaf, V. T., 2011. Stable Polyoxometalate Insertion within the Mesoporous Metal Organic Framework MIL100(Fe). Material Chemistry. 21: 1226-1233.

[3] Erhan, A.; Ilknur, E., and Seda, K., 2011, Adsorption and Transport of $\mathrm{CH}_{4}, \mathrm{CO}_{2}, \mathrm{H}_{2}$ Mixtures in a Bio-MOF Material from Molecular Simulations. The Journal of Physical and Chemistry C. 115: 6833-6840.

[4] Bin, M.; Paul M. S., and Krista, S. W., 2010. Gas Adsorption Study on Mesoporous Metal-Organic Framework UMCM-1. The Journal of Physical Chemistry C. 114 (14): 6464-6471

[5] Glover, G. T.; Gregory, W. P.; Bryan J. S.; David B., and Omar, Y., 2011. MOF-74 Building Unit has a Direct Impact on Toxic Gas Adsorption. Chemical Engineering Science. 66: 163-170.

[6] Qian-Rong, F.; Da-Qian, Y.; Julian, S.; Jian-Rong, L.; Zheng-Bo, H., and Hong-Cai, Z., 2010. Functional Mesoporous Metal-Organic Frameworks for the Capture of Heavy Metal Ions and Size-Selective Catalysis. Inorganic Chemistry. 49 (24): 11637-11642.
[7] Christopher W. J., 2011. $\mathrm{CO}_{2}$ Capture from Dilute Gases as a Component of Modern Global Carbon Management. Annual Review Chemical Biomolecular Engineering. 2: 31-52.

[8] Ya-Qian, L.; Hai-Long, J.; Shun-Li, L., and Qiang, Xu., 2011. Mesoporous Metal-Organic Frameworks with Size-Tunable Cages: Selective $\mathrm{CO}_{2}$ Uptake, Encapsulation of $\mathrm{Ln}^{3+}$ Cations for Luminescence, and Column-Chromatographic Dye Separation. Advance Material. 23 (43):5015-5020.

[9] Masaaki, S.; Teppei, Y., and Hiroshi, K., 2011. Hydroxyl Group Recognition by HydrogenBonding Donor and Acceptor Sites Embedded in a Layered Metal-Organic Framework. Journal of American Chemical Society. 133 (29):1105011053.

[10] Nicole, K.; Irena, S.; Kristina, G.; Ulrich, S.; Antje, H.; Uwe, M., and Stefan, K., 2009. Mesoporous Metal-Organic Framework. Angewandte Chemie International Edition. 48 (52) :9954-9957.

[11] Cheng, W.; Zhigang, X.; Kathryn, E. D., and Wenbin, L., 2011. Doping Metal-Organic Frameworks for Water Oxidation, Carbon Dioxide Reduction, and Organic Photocatalysis. Journal of American Chemical Society. 133 (34): 1344513454

[12] Young, K. P.; Sang, B. C.; Hyunuk, K.; Kimoon, K.; Byoung-Ho, W.; Kihang, C.; Jung-Sik, C.; Wha-Seun, A.; Nayoun, W.; Sungjee, K.; Dong. H., J.; Seung-Hoon, C.; Ghyung-Hwa, K.; Sun-Shin, C.; Young, H.; Jin, K. Y., and Jaheon, K., 2007. Crystal Structure and Guest Uptake of a Mesoporous Metal-Organic Framework Containing Cages of 3.9 and $4.7 \mathrm{~nm}$ in Diameter. Angewandte Chemie International Edition. 119: 1 -5 .

[13] Radu, C., and Bruce, A. M., 2007. Anion Separation with Metal-Organic Frameworks, European Journal of Inorganic Chemistry 2007 (10): 1321-1340.

[14] Hiroyasu, F.; Nakeun, K.; Yong, B. G.; Naoki, A.; Sang, B. C.; Eunwoo, C. A.; Özgür, Y.; Randall, Q. S.; Michael, O.; Jaheon, K., and Omar, M., 2010. Ultrahigh Porosity in Metal-Organic Frameworks. Science. 329 (5990): 424-428

[15] Sana, S., and Sibel, B., 2005. Synthesis of a New Cellulose Ion Exchanger and Use for the Separation of Heavy Metals in Aqueous Solutions. Separation Science and Technology. 40 (10): 2067 2078.

[16] Patricia, H.; Tamim, C.; Christian, S.; Brigitte, G.; Catherine, S.; Tarek, B.; Jarrod, E. D.; Pascal, C.; Christine, K.; Jong-San, C.; Young, K. H.; Veronique, M.; Phuong-Nhi. B.; Luc Cynober, S.; Gérard, F.; Patrick, C., and Ruxandra, G., 2010, Porous Metal-Organic- 
Framework Nanoscale Carriers as a Potential Platform for Drug Delivery and Imaging. Nature Materials. 9: 172-178.

[17] Amalia, M.; Roser, P.; Xavier, C.; and Michel, W. C. M., 2011. Imidazolium-Derived Organosilicas for Catalytic Applications. Catalysis Science \& Technology, 1: 1544-1563

[18] Andrew, D. W.; Estelle, S.; Qingyuan, Y.; Beatrice, M.; Vincent, G.; Mouna, B. Y.; Sandrine, B.; Alexandre, V.; Stuart, M.; Christelle V.; Marco, D.; Guillaume, C.; Christian, S.; Guillaume, M.; and Philip, L. L.; 2011. An Evaluation of UiO-66 for Gas-based Applications, Chemistry - An Asian Journal. 6: 3270 - 3280.

[19] Teply, F., 2011. Photoredox Catalysis by $\left[\mathrm{Ru}(\mathrm{bpy})_{3}\right]^{2+}$ to Trigger Transformations of Organic Molecules, Organic Synthesis using Visible-light Photocatalysis and its 20th Century Roots, Collection of Czechoslovak Chemical Communications, 76 (7): 859-917

[20] Neumann, M.; Füldner, S.; König, B.; and Zeitler, K.; 2011. Metal-Free, Cooperative Asymmetric Organophotoredox Catalysis with Visible Light, Angewandte Chemie International Edition. 50 (4): 951-954.

[21] Yi. C.; Qu-Li, F.; Pei, W.; Bing, Z.; Yan-Qin, H.; Guang-Wei, Z.; Xiao-Mei, L.; Hardy, S. On, C.; and Wei, H.; 2006. A Bipyridine-Containing Water-soluble Conjugated Polymer: Highly Efficient Fluorescence Chemosensor for Convenient Transition Metal Ion Detection in Aqueous Solution. Polymer, 47(15): 5228-5232.

[22] Zhang, B. S.; Qiu J. P.; Liu, L. H.; and Xu, W.; 2010. Tetra-aqua-(2,2' - bipyridine$\mathrm{kN}, \mathrm{N}^{\prime}$ )magnesium(II) Bis-(4-fluoro-benzoate), Acta Crystallographica Section E. E66: m1426$\mathrm{m} 1426$

[23] Jubaraj, B. B., 2011. Synthesis of First Row Transition Metal Carboxylate Complexes by Ring Opening Reactions of Cyclic Anhydrides. Journal of Chemical Science. 123 (2): 123-129.
[24] Capone, S.; De-Robertis, A.; De-Stefano, C.; and Scarcella, R., 1985. Thermodynamics of Formation of Magnesium, Calcium, Strontium and Barium Complexes with 2,2'-Bipyridyl and 1,10-Phenanthroline, at Different Ionic Strengths in Aqueous solution, Talanta. 32(8):675-677.

[25] Leslie, A.; Bishop, M. A. T., and Lawrence, B., 1998. Kool, Synthesis of Bipyridine and Biquinoline Complexes of Group 4-Metallocenes. Journal of Organometallic Chemistry. 553(1-2): 53-57.

[26] Marshall, W. E.; Wartelle, L. H., and Chatters, A. Z., 2001. Comparison of Attrition in Citric Acid Modified Soybean Hulls and Commercial Cation Exchange Resins. Industrial Crops and Products.13:163-169.

[27] Wartelle, L. H., and Marshall, W. E., 2000. Citric Acid Modified Agricultural by-Products as Copper Ion Adsorbents. Advances in Environmental Research. 4: 1-7.

[28] Altundogan, H. S.; Arslan, N. E., and Tumen, F. 2007. Copper Removal from Aqueous Solutions by Sugar Beet Pulp Treated by $\mathrm{NaOH}$ and Citric Acid. Journal of Hazardous Materials. 149 :432439.

[29] John, C. L.; and Keith, D., 1971. Determination of the Stability Constant of the Magnesium-ion Complex of Isocitrate. European Journal of Biochemistry. 23:194-197.

[30] Ochromowicz, K., and Apostoluk, W., 2010. Modelling of Carrier Mediated Transport of Chromium (III) in the Supported Liquid Membrane System with D2EHPA. Separation and Purification Technology. 72:112-117. 